\title{
Online Reputation in Automotive
}

\author{
Josef Vodák ${ }^{1}$, Milan Kubina ${ }^{1}$, Jakub Soviar ${ }^{1, *}$, Diana Zraková $^{1}$, and Patrik Ferenc ${ }^{1}$ \\ ${ }^{1}$ University of Žilina, Faculty of Management Science and Informatics, Univerzitná 8215/1, 01026 \\ Žilina, Slovakia
}

\begin{abstract}
This paper deals with the issue of online reputation, namely the social networking profile of businesses. Selected companies in the automotive industry through social profiles communicate with their customers, the public and they trying to improve their name and the name of their products in the public eye. Online reputation analysis was carried out to determine the current situation on the territory of Slovakia. On the basis of the data found, measures were proposed to improve the current state and reputation of automotive companies. Recommendations suggested by the findings can be used on any market to improve the current state and increase the competitiveness of automotive companies.
\end{abstract}

\section{Introduction}

The current turbulent market development causes a number of business challenges and opens up the question: how to maintain a positive corporate reputation for the long term or the reputation of its brands and products? At present, companies are still underestimating the power of reputation and reputation management. Because of understatement the power of reputation a number of companies lost what they have been building for years - a good name and an image. In order to, the companies lost everything in a short time, just only one bad step is enough. Customers and the public perceive every bad step - disrespect or deceptiveness or other information after a disappointment are very fast spread further, which contributes to the destruction of the good name and the positive opinions of the general public in very short time. For company si very easy loss of reputation, but repair the damage of reputation takes much longer and it is represent a conscious process - a reputation management process. Reputation management is the process of managing how companies, brands, or people are perceived around the business. The business environment is represented by customers, business partners, traders, competitors, journalists and the media, potential employees, as well as co-workers, investors, various personal contacts and other stakeholders. The goal of most of them is to protect the reputation of the company in the offline world, but also on the Internet by trying to prevent problems that revolve around the company's reputation. Reputation, online reputation, and trusted branding should be a priority for all companies.

\footnotetext{
* Corresponding author: jakub.soviar@,fri.uniza.sk
} 


\section{Reputation and online reputation}

Reputation can be defined as a summary of the attitudes, expectations and judgments of entities that are relevant to the company, which implies that the views, attitudes, expectations and judgments of all stakeholders have a direct or mediated influence on the enterprise and its activities [1]. Gattiker argues that reputation represents a collective expression of the enterprise's perception by several stakeholders on the basis of the efforts made by the company [2]. Fombrun's reputation attributes to businesses the ability to bring value to the business in addition to multiple stakeholders. According to the author, the reputation represents a set of internal relationships with employees and external relations with all stakeholders, partners and competitors [3]. Barnett and Pollock define the reputation as follows: Reputation is a prediction of future behaviors, which is based on an assessment of how past behaviors met the expectations following the comparison of social status [4].

Reputation is related to company strategy and must be in line with marketing strategy $[3,5]$. Reputation is a value for stakeholders that represents product quality assurance. It is also important in terms of marketability and competitiveness. Creating reputation consists in building the knowledge, orientation and confidence of the business in certain parts towards the public in order to maintain customer value. Reputation is a very important. It decides on the future behavior of stakeholders towards the business. Positive reputation enhances performance, helps to withstand risks, and helps buyers to help with buying decisions [6-9]. In order to promote positive reputation, it is necessary to keep in touch with our customers. Communication reflects corporate culture. If companies want to maintain a positive reputation and get loyal to customers, they must constantly communicate with them, in short, to know their entire audience [10]. For this reason, its necessary to do an audience survey, for example on social networks. Authors say, that individuals are focusing around the companies or brand for the obvious reason online. Customers concentrate on social networks around automobile compartments for the purpose of collecting and exchanging information, interacting with each other [11, 12]. Social networks enable organizations to communicate regularly with clients and the public about crisis events, among other things in crisis situations. The public has the opportunity to respond to emerging crisis situations through social networks and can remove the uncertainty they experience. If public reactions are negative, company should respond appropriately and respond truthfully, which is beneficial for its reputation [13].

Online reputation represents an image of how the public and stakeholders are perceived by an enterprise when searching in the online environment. Online reputation can include news articles, blog posts, social profiles, and all the information that can be found and retrieved by search engines. Vartiak also states that there are three steps in building the right online reputation and are as follows [14]:

- monitor and search for what is said online about the business and its products,

- analyze how the visible information affects the reputation of the company, the brand or its products,

- influence outcomes and eliminate negative feedback by participating in communication.

The overall reputation of the business depends on how the companies perceives individual stakeholders in both online and offline environments. The better the stakeholders are perceived by society, the more positive the company has in its overall reputation. 


\section{Survey}

The survey in this article focused on the analysis of online reputation in automotive in Slovakia. The purpose of the survey was to compare the profiles on the selected social network in which the individual carmakers build their reputation. This survey should have as certain the current state of reputation of selected automotive companies among Slovak residents.

The Facebook social network has been selected, as it is one of the most popular in Slovakia. In analyzing company profiles on the social network, the following weighting factors were selected: number of fans / followers with assigned weight 4 , the number of posts for the last month with assigned weight 3, average number of posts per week with assigned weight 2 , management response time with weights of 4 and interaction with users (the number of responses to comments) weighing 3 . The weights of the individual factors were on the scale from 1 to 5 ( 5 being the most important factor and 1 the least important factor). Table 1 lists the values which are then multiplied by the weights and the resulting values given in Table 2 are calculated.

However, the time for the response to the management was to be recalculated to maintain the conversion methodology as for the other factors. Message response time was Škoda one day, for Volkswagen 2 hours, Kii 3 minutes and Peugeot and Land Roveri one day. The resulting recalculation of response time is based on the assignment of penalty points. For every minute of the management response delay, the -1 value was deducted.

Table 1. Profile Analysis on Facebook Social Network. Source: authors

\begin{tabular}{|c|c|c|c|c|c|}
\hline Company & $\begin{array}{c}\text { Number of } \\
\text { fans }\end{array}$ & $\begin{array}{c}\text { Number of } \\
\text { posts }\end{array}$ & $\begin{array}{c}\text { Average } \\
\text { number of } \\
\text { posts per } \\
\text { week }\end{array}$ & $\begin{array}{c}\text { Management } \\
\text { reaction time }\end{array}$ & $\begin{array}{c}\text { User } \\
\text { interaction }\end{array}$ \\
\hline Škoda & 59802 & 23 & 4 & -1440 & $\begin{array}{c}\text { high } \\
\text { replies })\end{array}$ \\
\hline Volkswagen & 19365 & 24 & 4 & -120 & $\begin{array}{c}\text { high } \\
(3 \text { replies })\end{array}$ \\
\hline Kia & 60019 & 30 & 6 & -3 & $\begin{array}{c}\text { high } \\
(3 \text { replies })\end{array}$ \\
\hline Peugeot & 10825350 & 27 & 5 & -1440 & $\begin{array}{c}\text { middle } \\
(2 \text { replies })\end{array}$ \\
\hline Land Rover & 14016 & 20 & 3 & -1440 & $\begin{array}{c}\text { middle } \\
(2 \text { replies })\end{array}$ \\
\hline
\end{tabular}

In the above table, information on selected automotive companies is identified by analysis. For each company, results are shown for each factor. It can be seen that Peugeot has the most fans on its official facebook profile. This factor is assigned the highest weight 4. With this number of fans, the question arises as to whether it really is due to a great company activity or that fans are split into a number of officially verified facebook profiles of companies with global reach, while Peugeot does not have such official worldwide sites, respectively. are not easily viewable. Land Rover has the least fan, which may be due to the fact that this company is not a long-time producer on the Slovak market, so it is not even in the awareness of most Slovaks. However, this fact may change in the future.

For the second factor with a fairly high weight, it can be seen that the number of contributions is in all cases greater than 20. In all cases, except for Kia and Peugeot, the contributions to the social network were roughly the same. In terms of the number of posts per week, Kia is again winning, much like the reaction time factor. Kia, unlike other 
companies, uses a social network for its reputation. Kia responds to a comment or social networking from the public in minutes. Volkswagen is also relatively good in this area. It can give feedback within two hours. Other companies are neglecting feedback as they respond to contributions post-dated. The last factor of interacting with users is not very large. The number of responses to comments is roughly the same for all selected companies.

Table 2. Overall rating of individual companies. Source: authors

\begin{tabular}{|c|c|c|c|c|c|c|c|}
\hline Company & $\begin{array}{c}\text { Number } \\
\text { of fans }\end{array}$ & $\begin{array}{c}\text { Number } \\
\text { of posts }\end{array}$ & $\begin{array}{c}\text { Average } \\
\text { number } \\
\text { of posts } \\
\text { per week }\end{array}$ & $\begin{array}{c}\text { Manageme } \\
\text { nt reaction } \\
\text { time }\end{array}$ & Interaction & Sum & Company \\
\hline Škoda & 239208 & 69 & 8 & -5760 & 9 & 233534 & Škoda \\
\hline VW & 77460 & 72 & 16 & -480 & 9 & 77077 & VW \\
\hline Kia & 240076 & 90 & 12 & -12 & 9 & 240175 & Kia \\
\hline Peugeot & 43301 & 81 & 10 & -5760 & 6 & 43295 & Peugeot \\
\hline $\begin{array}{c}\text { Land } \\
\text { Rover }\end{array}$ & 56064 & 60 & 6 & -5760 & 6 & 50376 & $\begin{array}{c}\text { Land } \\
\text { Rover }\end{array}$ \\
\hline
\end{tabular}

From the results shown in Table 2, a sovereign winner can be seen in the care of his reputation on the Facebook social network. The winner in this area is Peugeot, who leads the table with a big lead. If we do not think about this company, since it seems to have accumulated all customers on one social network, the best company would be Kia. This company excels in several factors. It has high interaction and the lowest response time for messages, it has the largest number of posts and fans. No serious deficiencies were found in analyzing facebook profiles of all carmakers. Several of the selected car manufacturers were mistaken for mileage information and also provided various information about the foundations. Škoda and Peugeot show the year of founding the whole company, not just the Slovak branch. Land Rover does not mention this information at all. Kia reports the creation of a facebook profile. More important information missing from most of the contact was at least the email address. If a contact customer wants a company and does not want to communicate through the social network only, they must rejoin the company's official website to find contact information. All of the analyzed profiles were almost completed, they were active and verified.

Based on the analysis of profiles on the social network, the following ranking was drawn: Peugeot first, second Kia, third Škoda, fourth Volkswagen and the last Land Rover.

From the analysis of individual companies and their efforts to maintain constant communication with customers, each of the rated companies uses the phenomenon of social networks to their advantage and their profiles are trying to regularly interact with the fans.

It is also possible to argue that despite the fact some of the carmakers have done some repairs, their reputation did not have a great impact on the territory of the Slovak Republic. Despite the scandal that has been published, customers continue to buy these brands and continue to support them and communicate with their facebook posts. As an example, it is worth mentioning Kia's fiasco in the US and Canada. In 2012, Kia mistakenly reported lower car consumption than it actually did. Customers perceived this situation as a big deception and misappropriation. The reputation of the company suffered a loss and also suffered as a drop in shares [15]. The second example is Volkswagen and the famous dieselgate case, when the carmaker falsified emissions tests not only for the Volkswagen brand, but also Škoda, Audi and Seat [16]. 


\section{Conclusion}

Due to the constantly increasing innovation potential and business digitization, it is necessary not only to invest time, money and energy in online reputation not only in the real world but also in the virtual world. It impacts on customers, the public, and other stakeholders. Online reputation encourages the need to invest free assets in products and services with a positive reputation. Since, at present, many companies do not pay much attention, its importance must be highlighted.

Based on the survey conducted by selected companies in the automotive field, it can be argued that, despite the publicly known and still current under-estimation of the strength and the importance of reputation, the state of online reputation in the selected area is above average.

Despite the positive current situation of selected companies, it is worth recalling and proposing measures for improvement. To improve online reputation, it is necessary to have a full profile on the social network so that the customer can learn as much information as possible in one place and, of course, cannot even be mistaken for the official website of the car offer. It is advisable to provide contact details on the social network so that the customer does not have to search for the necessary information when contacted.

Even on the basis of selected factors, it is clear that you need to respond promptly to all the comments and reactions of your customers, fans or the public. If the business is active and decent and engaging with the public, it will feel that the business is interested in it and it depends on it. It is important to create a confidential relationship between customers and fans. It is clear that the company does not always meet on the social network with positive reactions only. In this case, it is important not to delete the post, because for others it can act as concealment, an inability to cope with a negative situation, and it can give fans and customers a feeling of insecurity and deception.

For customers, it is important for businesses to be active and to learn from them. This implies that businesses should add more frequent contributions to the different events they participated in, news in the field of planned actions or, for example, price shares, but also, for example, news from the field of planned model series innovations and the like. Businesses should also encourage their fans to work, for example, trying to induce communication with the addition of photos of their "four-crowned pets" in a story, or the situation and the owner of the best photo for which the general public would vote would be rewarded by a little bit.

It follows that automotive companies are able to increase their reputation by busy, decent and active communication through official profiles on social networks that need to be maintained and must be taken care of by the company. Trust, loyalty, and truthfulness are incredibly important for customers, and businesses should strive to achieve the best and most trustworthy relationship with their fans and customers, as well as the public. Online marketing is also influenced by marketing and various marketing activities as outlined above. Businesses should be aware that it is sometimes better to take advantage of smaller and less expensive marketing activities distributed through social networks, especially because of low implementation costs and the ability to work on different segments at the same time. To increase online reputation, it is also important to act ethically, socially and professionally to the public. It is for this reason that the business should highlight all its activities in this area and publish it on its social networking profile, thereby also presenting customers with the willingness to contribute not only to improving their products but also to improving the global situation in the world.

This article is supported by the Slovak research and Development Agency under the contract No. APVV-15-0511. 
This paper is supported by the research project "From horse-drawn railway to intermodal transport" within Visegrad Fund.

\section{References}

[1] J. Klučka, Good name is difficult to get and easily lose (Dobré meno sa t’ažko získava a l'ahko stráca) (In Slovak), Available online: https://www.etrend.sk/podnikanie/dobre-meno-sa-tazko-ziskava-a-lahko-straca.html (2006)

[2] U.E. Gattiker, Brand versus reputation, Available online: http://commetrics.com/articles/branding-versus-reputation-jeff-bezos-richard-bransonjosef-ackermann-and-pat-russo-to-the-rescue/ (2008)

[3] C.J. Fombrun, C. Van Riel, Corporate Reputation Review, 5-13 (1997)

[4] M.L. Barnett, T.G. Pollock, The Oxford Handboook of Corporate Reputation, 528 p. (OUP Oxford, UK, 2012)

[5] Š. Hittmár, Management (Manažment) (In Slovak), 301 p., (EDIS, University of Žilina, Slovak Republic, 2006)

[6] M.L. Barnett, J.M. Jermier, B.A. Lafferty, Corporate Reputation Review 9, 1, 26-38 (2006)

[7] R.J. Burke, G. Martin, C.L. Cooper, Corporate Reputation: Managing Opportunities and Threats, 356 p. (CRC Press, 2016)

[8] V.A. Knipp, Trust the Brand - Corporate Reputation Management in Private Banking, 148 p. (Diplomica Verlag, 2009)

[9] J. Vaculčiaková, Reputation affects the value of the business (Reputácia ovplyvňuje hodnotu firmy) (In Slovak), Available online: http://www.etrend.sk/podnikanie/reputacia-ovplyvnuje-hodnotu-firmy.html (2003)

[10] R. Burkhardt, Reputation Management in Small and Medium-sized Enterprises: Analysis and Evaluation of the Use of Reputation Management. A Survey of Small and Medium-sized Enterprises in Germany, 122 p. (Diplomica Verlag, 2008)

[11] J. Gutiérrez-Cillán, C. Camarero-Izquierdo, R.S. José-Cabezudo, How brand post content contributes to user's Facebook brand-page engagement. The experiential route of active participation, 258-274 (2017)

[12] E.D. Raj, L.D.D. Babu, An enhanced trust prediction strategy for online social networks using probabilistic reputation features, 412-421 (2017)

[13] H. Crijns, V. Cauberghe, L. Hudders, A. Claeys, How to deal with online consumer comments during a crisis? The impact of personalized organizational responses on organizational reputation (2017)

[14] L. Vartiak, Transcom Proceedings, Section 2: Economics and Management, 270-276 (2015)

[15] B. Benčat, Hyundai and Kia have made a hard hit on the consumer fiasco. (Hyundai a Kia tvrdo doplatili na fiasko so spotrebou) (In Slovak), Available online: https://www.etrend.sk/auto/hyundai-a-kia-tvrdo-doplatili-na-fiasko-so-spotrebou.html (2012)

[16] M. Kern, Which cars are related to an emission scandal and what are their owners waiting for in the near future? (Akých áut sa týka emisný škandál a čo ich majitel'ov $v$ najbližšom čase čaká) (In Slovak), Available online: https://dennikn.sk/254341/akychaut-sa-tyka-emisny-skandal-a-co-ich-majitelov-v-najblizsom-case-caka/ (2015) 